\title{
How Is the Performance of Chinese News Media in Kenya? An Analysis of Perceived Audience Reception and Motivation
}

\author{
Abdirizak Garo Guyo ${ }^{1,2^{*}}$ Hong $\mathrm{Yu}^{1}$ \\ 1. School of Journalism and Information Communication, Huazhong University of Science \& Technology, 1037 \\ Luoyu Rd. Wuhan 430074, China. \\ 2. Kenya Institute of Mass Communication, P.O Box 42422-00100, Nairobi, Kenya.
}

\begin{abstract}
In the past decade, Chinese national news media have stepped up their efforts to spread their influence across the globe, including in Africa. This study sought to explore the extent to which these media were able to satisfy the needs of their target audience in Kenya. Based on a cross-sectional survey in Nairobi $(\mathrm{N}=355)$, the results showed that the audience reception of China's media was fairly satisfactory, with CCTV Africa being touted as the most commonly accessible Chinese media by the respondents. Although there was statistically significant difference in the audience motivations for their perceived use of Chinese media contents, and their level of education, the final result suggested that the audience perceptions of China's media coverage of African issues was relatively adequate. This study concluded that though their consumption was limited, these media were able to contribute to some knowledge on Sino-Africa relations.
\end{abstract}

Keywords: Audience; China's news media; coverage; gratifications; Kenya

DOI: $10.7176 / \mathrm{NMMC} / 79-06$

Publication date: April $30^{\text {th }} 2019$

\section{Introduction}

In the past decade, the Chinese national news media have made great strides in their efforts to expand their presence across the globe, including in Africa. Between 2006 and 2012, China's state media have pursued pragmatic expansionist's strategies across Africa, especially in the Sub-Sahara African countries, as part of Beijing's public diplomacy to tell the continents' and China's story to the world and vice versa. This presence has grown and become more diverse, particularly in large African media markets (Wasserman \& Morlaes, 2018), with several state-owned Chinese media houses having established offices on the continent, especially in Kenya and South Africa (Wasserman, 2016).

This expansion of Chinese media in Africa can be viewed as providing a platform for other developing countries to reach an international audience (Zhang \& Matingwina, 2016). In addition, the increased presence of Chinese media on the continent has formed part of broader strategic aims, as part of multi-lateral agreements and partnerships aimed at promoting the country's profile abroad (Wasserman, 2018), while representing the interests of Chinese government (Xiang, 2018). These efforts were also aimed at increasing Chinese soft power in Africa (Zhang \& Mwangi, 2016; Nassanga \& Makara, 2016). The concept of soft power is associated with former American diplomat and Harvard professor Joseph Nye, who defined it as the ability to produce outcomes through persuasion and attraction rather than coercion and payment. According to Nye (2008) soft power of a country rests on three resources; its culture, its political values and its foreign policy.

Although a great deal of scholarly work has been done on the presence of China's media in Africa, locally, not much empirical research were undertaken to appraise their performance from the audience perspectives. Recent studies (Wasserman \& Madrid-Morales, 2018; Gorfinkel et al., 2014) jointly done in Kenya and South Africa, 
showed that the audience reception of Chinese news media in both countries was limited. While the Kenyan audience demonstrated a fairly significant level of knowledge about the presence of Chinese media in the country, their South African counterparts indicated responses ranging from little to non-existent awareness about these media. These findings concurred with a study conducted in Kenya (Zhang \& Mwangi, 2016) which showed that the general awareness of the presence of Chinese media in Kenya was limited.

However, in both of the studies (Wasserman \& Madrid-Morales, 2018; Zhang \& Mwangi, 2016), the young and educated members of the audience in Kenya demonstrated better understanding and awareness about the presence of Chinese news media in the country. Therefore, drawing on these studies, this paper aims to explore in depth the extent to which the Chinese news media were able to satisfy the needs of their Kenyan audiences. This study begins by establishing the audience exposure to Chinese media, and the most accessible Chinese media outlet, the audience possible motivations for the use of these media, and finally their perceptions of China's media coverage of African issues.

\subsection{An overview of Chinese media in Africa}

China's engagement with Africa dated back to several centuries ago. However, in terms of communication link, China and Africa have had engagements with each other for more than five decades, as available evidence (Bailard, 2016; Wu, 2012) suggested that the Chinese media have been broadcasting in Africa as far back as 1950s. This was the period when most of the African countries were agitating for independence against the colonial rule on the continent. According to $\mathrm{Wu}$ (2012) however, media co-operation has developed more slowly and unevenly than other aspects of the China-Africa bilateral relationship.

However, in terms of Beijing's media engagements with Africa, one of the earliest Chinese state media that had set its footprint in Africa is China Radio International (CRI) whose presence in the continent date back to the late 1950s. Bailard (2016) indicated that the CRI began broadcasting in Africa specifically in 1956 (as then-named Peking Radio). By 1965, CRI broadcast "nearly 100 hours a week, making it 'the best-known and most effective propaganda channel of Red China in Africa" (Shinn \& Eisenman, 2012; as cited in Bailard, 2016). Bailard argued that although China has been transmitting radio broadcasts to Africa for more than half a century, both the quantity and quality of these transmissions have expanded over recent years.

The CRI established its African hub in Nairobi and commenced local broadcasting in 2006 (Wekesa, 2013). In 2009, CRI formed more partnerships with local stations and added six new languages to its broadcasts, including its Kiswahili service in Kenya (Zhang \& Mwangi, 2016). In Kenya, CRI launched its own local FM stations in three East African cities, broadcasting in English, Mandarin and Swahili, and with AM channel coverage across the country (Wu, 2012).

Like other international radio stations, the CRI created programmes that are specifically made for their African audiences and started broadcasts in French in West African countries such as Mali and other local languages like Hausa and Swahili in other countries (Diakon \& Röschenthaler, 2017).These strategies were aimed at widening the scope of the CRI and tap into the wider segment of its African and other global audience. Further, 
Cooper(2008) claimed that there is already evidence in Kenya to show that CRI enjoys a relatively high degree of listenership and trustworthiness as it had set up its own broadcasting station, and also entered into programme exchanges with the Kenya Broadcasting Corporation (KBC) ( as cited in Banda, 2009).

Similarly, the Chinese state news agency Xinhua, has had a fairly long presence in the continental media scene spanning to over five decades. Xinhua started its activities in sub-Saharan Africa as early as the late 1950s (Xin, 2009). Additionally, Wu (2012) argued that Xinhua's early presence in Sub-Saharan Africa was to help the Chinese government form diplomatic relations with recently independent African states. However, in the 2000s and 2010s, the news agency, has significantly expanded its scope and reach in Africa (Gagliardone \& Pál, 2017). These authors argued that Xinhua has several bureaus in Sub-Saharan Africa, the largest coverage of any news agency, and its news stories have begun to appear regularly in national newspapers. This strategy is in tandem with the broader China's renewed interest in Africa. Moreover, Grassi (2014) indicated that Xinhua has 30 bureaus, 60 journalists and 400 local employees on the continent. In 2006, Xinhua relocated its regional editorial office for Africa from Paris, France to Nairobi, Kenya (Gagliardone, 2013). This is a clear manifestation that the Chinese media have stepped up their efforts to consolidate and strengthen their base in the continent. The official Chinese news agency had also provided support for the news agencies of African liberation movements in the form of material aid and journalist exchanges (Grassi, 2014; Shin, 2012).

To further expand the presence of its media in Africa, Gagliardone (2013) stated that in 2011, the Chinese national broadcaster China Central Television (CCTV), made its debut into the continent, about a decade after it started international broadcasting program in 2000. To produce more relevant and appealing content to African viewers, in 2011, CCTV established the network's regional center for Africa in Nairobi, Kenya (Bailard, 2016).This effort was aimed to provide a Chinese perspective to the growing market of international news channels such as Al Jazeera, the British Broadcasting Corporation (BBC), and Cable News Network (CNN) (Gagliardone, 2013).This venture made CCTV to become the largest non-African TV initiative in Africa, employing more than 100 journalists, mostly African, between its headquarters in Nairobi and reporting from across the continent (Gagliardone \& Pál, 2017).

In 2012, the same year CCTV Africa started operating, the state-controlled English-language newspaper China Daily launched its Africa weekly edition (Gagliardone \& Pál, 2017; Zhang, 2013). Headquartered in Nairobi, this edition is a weekly twenty-four-page publication that covered issues specific to Africa-China relations (Bailard, 2016). The opening of China daily bureaus in Johannesburg and Nairobi has extended the newspaper's reach to English-language readers in these major African centres, as well as online (Wasserman, 2015). Therefore, CCTV Africa, which has since rebranded to China Global Network Television (CGTN), hereafter referred to as CCTV/CGTN ${ }^{1}$ and China daily African edition were the last two of the Chinese state media that have established their presence in Africa after the national news agency, Xinhua and the CRI.

Ironically, the expansion of Chinese media across the world generally, and Africa specifically, came at a time when other global news groups were closing down their non-essential foreign offices in order to focus on their 
respective domestic audiences (Marsh, 2016; Gagliardone \& Verhoeven, 2012).Separately, (Gagliardone, 2014; Gagliardone \& Pál, 2017) observed that Chinese media were among the few that were able to boost operations in Africa when other outlets were pulling out from the continent due to financial crisis.

The expansion of Chinese national media in Africa has also attracted the attention of other international media players such as BBC and CNN. For instance, reacting to the launch of China daily African edition, BBC (2012) reported that this latest of several Chinese media initiatives in Africa, was part of China's push to increase its international media presence, including in the US. While CNN reported that China's media strategy in Africa has taken a step further by providing customer-oriented news offerings and poaching some of the best journalistic talents to bring African news to the continent and to the world (McKenzie, 2012).

\subsection{The perceptions of Chinese media in Africa}

Media engagement in Africa is a component of China's contemporary strategy of public diplomacy, which is aimed at promoting deep bilateral diplomatic and economic relations (Wu, 2016). Conversely, Jiang et al. (2016) argued that one of the major aims of Chinese media global expansion in general, and Africa in particular, has been to establish an alternative to the "Western" news agenda in coverage of the African continent. In this regard, China's news media serve two purposes; to give Africa an alternative forum through which its voices can be heard. Then, since China has also equally suffered the same fate that the continent endured from the Western media coverage, Beijing therefore aimed to utilize its state media for her voices to be heard in the global media arena. Moreover, China wanted to increase its influence and build a positive image for itself in Africa, as much as in other parts of the world (Zhang et al., 2016), while also working on the dual task of building influence and spreading a positive image of China-Africa relations, at home and abroad (Li \& Rønning, 2013).

Further, Li and Rønning (2013) noted that many stories about Africa in the Chinese press are not so unlike the reports that one finds in the Western media about African developments. This is in stark contrast with the western media contents that for far too long painted the African picture in negative narratives. Much of the continent's news genres in the western media were dominated by themes bordering on conflicts, crisis, poverty and poor governance. Nonetheless, with ongoing and mounting threats to its image in the world press and in the Africa media, China has devised a multifaceted strategy to influence African public opinion and the African media (Leslie, 2016).

Therefore, the establishment of CCTV in Nairobi is viewed as part of China's renewed attempt to foster positive perceptions of China and share 'China's views' on international issues with the world and build positive image of China in Africa (Gorfinkel et al.,2014). Wasserman (2013) argued that by telling a positive story of Africa, and tapping into the 'Africa rising' narrative, CCTV can position China as an ally of African states who have long had to fight against negative reporting by the West.

Similarly, Gagliardone (2013) noted that CCTV Africa has been seeking to influence perceptions of China and of Chinese engagement on the continent, not by directly offering an alternative image of China, but by advancing new ways of looking at Africa. Zhang and Mwangi (2016) observed that Chinese media had helped to promote the public's understanding of China, and their role was viewed as providing an alternative channel of 
information with potential benefits for Sino-Kenyan relations. Moreover, Wekesa (2013) pointed out that the role of the Chinese media seemed to be directed at shaping positive perceptions, in order to secure China's economic and diplomatic objectives.

According to Zhang and Mwangi (2016) it is largely perceived that China's media will offer a different narrative from Anglo-American coverage thus playing a vital role as alternative media in Africa, which is appreciated by the Kenyan public for its positive and constructive report on Africa. However, Wasserman (2016) reasoned that although Chinese media may be a potentially useful vehicle to disseminate Chinese perspectives to global audiences, the messages carried by these media cannot be assumed to have a direct effect on local audiences. Further, Wasserman (2018) argued that the Chinese media content also did not seem engaging enough for it to be included in local news agendas, sought out by local journalists. The 'China story' would only enter local news agendas when it impacted on local politics or economic matters. Thus, despite having substantially increased their presence, Chinese media are far from having a profound impact on media professionals (Madrid-Morales \& Wasserman, 2017).

Moreover, Finlay (2013) asserted that China's 'soft power' approach was having something of a positive influence on local media coverage through the simple tactic of making official sources directly available to journalists. In the same vein Zhang et al. (2016) suggested that China's state-led soft power initiatives on the continent have achieved some desired results. However, Zhang and Mwangi (2016) observed that the engagement of Chinese media as a soft power in Kenya has not yet shown the intended effects. In the same vein Wasserman (2016) alluded to the fact that China's attempts to use media to exert soft power in South Africa will continue to be met by considerable challenges.

Nevertheless, Bailard's analysis suggested that China's post-2006 media expansion on the continent may be having the desired effect on African public opinion. The author further argued that, in many cases, the larger the Chinese media presence in a country, coupled with access to relevant media technology, the more favorable public opinion toward China has grown across multiple dimensions. Similarly, Nassanga and Makara (2016) pointed out that although the literature review of general perception of China in the west revealed its predominantly negative image, their findings showed that the local perception of China in Uganda and elsewhere in Africa are largely neutral and positive, rather than negative.

Therefore, the foregoing literatures on the perceptions of Chinese news media in Africa revealed mixed results that were oscillating between positive receptions to negative portrayals, while sometimes depicting it as indifferent.

This study was grounded on the theoretical framework of the Uses and Gratifications approach which underscores that media researchers, ought to be studying human needs to discover how much the media do or do not contribute to their creation and satisfaction (Katz et al., 1973). The uses and gratifications perspective is often employed to examine audience uses of mass media according to social and psychological needs such as 
surveillance, escape, boredom, and entertainment needs (Vincent \& Basil, 1997). And that the audience's motivations and uses of the media are determined by their need for information, diversion, curiosity and personal identity (Blumler, 1979). Consequently, the Chinese news media have the Uses and gratifications functions in Kenya, in which they are expected to satisfy the needs and meet the interests of their audiences by providing them with media contents and products that are relevant and appealing to their varying levels of gratifications sought. This can be done either directly as content providers, as in the case of CCTV/CGTN, CRI and China Daily or indirectly in the case of Xinhua. Therefore, drawing on the Uses and Gratifications perspective, the following research questions were formulated for this study.

\subsection{Research questions}

RQ1. What is the most widely available (accessible) Chinese media outlet in Kenya?

RQ2.What are the gratifications most sought from the use of these media?

RQ3.To what extent have the perceived coverage of Chinese media in Africa met the audience satisfactions?

\section{Research Method}

The study employed the use of exploratory cross-sectional survey approach in which the data were collected amongst the sample population of the universities and college students in Nairobi, Kenya. A cross-sectional survey is the most frequently used method to provide information about current status of peoples' attitude on a specific topic (Gunter, 2000).

Recent studies (Wasserman and Madrid-Morales, 2018; Zhang and Mwangi, 2016) showed that generally the young and educated members of the audience were more knowledgeable about the Chinese media in Kenya. Therefore, building on these exploratory studies, this study employed the use of sample population of the universities and college students in Nairobi to establish the performance of the Chinese news media among the Kenyan audience. Nairobi is also a hub to most of the international media outlets including China's national news media, which is the focus of this study. To ensure a representative sample is attained, students both in public and private universities ${ }^{2}$, and a national college, as well as fulltime, and part time students were incorporated.

Based on the available list of all the universities in the country, a final list of 25 universities in Nairobi, 13 public and 12 private universities was compiled. Using a random sampling technique ${ }^{3}, 3$ universities were picked from each of the two categories. The selection of the respondents was done by use of stratified sampling method based on gender and their level of studies to ensure fair representations in the sample. Once this was achieved, simple random sampling was used to select the respondents for the study. The data collection was done by use of close-ended questionnaires administered with an aid of two trained research assistants and a lead researcher between January 2018 and February 2018, over a period of 3 weeks. Before the task of quantitative data analysis commenced, researchers recruited two post graduate students who were trained in order to complete the coding process.

The first part of the questionnaire sought the demographic details of the respondents such as their gender, level of education and the type of university attended. In the subsection, the respondent's exposure to Chinese media 
in Africa was asked; ("have you ever been exposed to Chinese news media in Africa4?").This was followed by their frequency of exposure; ("how often have you been exposed to these media in the past one month?"). The next question sought the respondent's exposure to specific media; ("what Chinese media outlet do you access most often?"). Drawing on Blumler's (1979) suggestion, the next part of the questionnaire explored the respondent's perceived motivations to use the Chinese media to gratify certain needs. While in the final part, the audience perception of China's media coverage of African issues was interrogated.

\section{The Results and Findings}

\subsection{Demographic details}

A total of 420 questionnaires were distributed among the respondents from six universities, three each representing both the public and the private universities, and a national college. In total, 355 questionnaires were dully completed and returned, representing a response rate of $84.5 \%$. The final results indicated that there were 195 males and 160 females of the total population of 355 polled for the survey, accounting for $54.9 \%$ and $45.1 \%$ respectively. In terms of type of university, public universities accounted for $68.7 \%$ with 244 respondents while private universities constituted 111 respondents, representing $31.3 \%$ of those polled.

With regard to level of education, initially four levels were constructed in the questionnaire; however, the certificate level was dropped when it was found that their level of knowledge and understanding about the topic under investigation was not appropriate with questions posed to them. Nonetheless, $4(1.1 \%)$ of those polled were at the certificate level, 106(29.9\%) were diploma, while the majority of the respondents $238(67 \%)$ were degree students and $7(2 \%)$ of the respondents representing post graduate level of education.

\subsection{The most accessible Chinese media outlet}

Overall, a total of $243(\mathrm{n}=355)$ respondents, representing $68.5 \%$ of those polled indicated that they had been exposed to Chinese media in Kenya. However, in terms of their frequency of consumption in the past one month, $3.3 \%$ (8) used it rarely while $96.7 \%$ (235) did not engage any of these media outlets at all. To establish the most accessible Chinese media outlets, the respondents were asked to multi-select their choices from the list provided. The results showed that CCTV/CGTN was the most prevalent with 117 respondents $(48.2 \%)$, followed by China Radio International (CRI) at 77(31.7\%), with China daily closing the three most commonly accessible media accounting for $38(15.6 \%)$ of the respondents. However, the national news wire service, Xinhua, attracted $11(4.5 \%)$ of those polled.

\subsection{Gratifications sought from the use of Chinese media}

In order to establish the audience perceived gratifications sought from the use of Chinese media, the respondents were required to select their motivations for the use of Chinese news media from the options provided; (a) to get nonwestern, (b) non-local contents (as information needs), (c) for entertainment (diversion), (d) to know more about China (curiosity), and (e) to make friends with Chinese (personal identity).

The results suggested that the majority of the respondents $153(63 \%)$ indicated their perceived motivations for the use of Chinese media in order to get non-western contents while $45(18.5 \%)$ wanted to have contents that were 
different from the local contents. Another 23(9.5\%) of those polled wanted to know more about China while $16(6.6 \%)$ cited entertainment as their motivation for their use of these media outlets. However, $4(1.6 \%)$ of those polled identified to make friends with Chinese while another $2(0.8 \%)$ of the respondents simply picked other as their choice.

Table 1.The relationship between the main variables of this study and the motivations for the use of Chinese media.

\begin{tabular}{|c|c|c|c|c|c|c|c|c|c|c|}
\hline & Motivation fo & Chinese me & a use & & & & & Chi-square & & \\
\hline Education level & Non- western & Non-local & Entertainment & Know China & Make friends & Other & Total & & df & $P$ \\
\hline Certificate count $\%$ within & $2(1.3)$ & $1(2.2)$ & $0(0)$ & $0(0)$ & $0(0)$ & $0(0)$ & $3(1.2)$ & 32.287 & 15 & .004 \\
\hline Diploma count $\%$ within & $28(18.3)$ & $18(40)$ & $4(25)$ & $10(43.5)$ & $1(25)$ & $2(100)$ & $63(25.9)$ & & & \\
\hline Degree count $\%$ within & $121(79.10)$ & $24(53.3)$ & $12(75)$ & $13(56.5)$ & $2(50)$ & $0(0)$ & $172(70.8)$ & & & \\
\hline $\begin{array}{l}\text { Post- graduate count } \% \\
\text { within }\end{array}$ & $2(1.3)$ & $2(4.4)$ & $0(0)$ & $0(0.0)$ & $1(25)$ & $0(0)$ & $5(2.1)$ & & & \\
\hline Total count $\%$ within & $153(100)$ & $45(100)$ & $16(100)$ & $23(100)$ & $4(100)$ & $2(100)$ & $243(100)$ & & & \\
\hline Gender & & & & & & & & & & \\
\hline Male count $\%$ within & $103(67.3)$ & $22(48.9)$ & $9(56.2)$ & $10(43.5)$ & $3(75)$ & $1(50)$ & $148(60.9)$ & 8.886 & 5 & .114 \\
\hline Female count $\%$ within & $50(32.7)$ & $23(51.1)$ & $7(43.8)$ & $13(56.6)$ & $1(25)$ & $1(50)$ & $95(39.1)$ & & & \\
\hline Total count $\%$ within & $153(100)$ & $45(100)$ & $16(100)$ & $23(100)$ & $4(100)$ & $2(100)$ & $243(100)$ & & & \\
\hline
\end{tabular}

Note: values in parentheses are in percentage.

Chi-square test result $\left(\chi^{2}=32.287, d f=15, p=.004\right)$ showed that, since $\mathrm{p}=0.004<0.05$, the motivation for the use of Chinese media is statistically significant between different levels of education. However, Chi-square test result $\left(\chi^{2}=8.886, d f=5, p=.114\right)$ showed that there was no statistically significant difference in motivation between the males and females. This result suggested the homogeneity of the sample population.

\subsection{Perception of Chinese media coverage of Africa}

In order to gauge the Chinese media's coverage of Africa and African issues, the respondents were provided with a set of statements on thematic areas that were perceived to constitute the contents of the Chinese news media in Africa. Using a five-point Likert scale, (1 strongly disagree, 5 strongly agree), the respondents were asked to rank some of the commonly held possible attributes of Chinese media contents. Their responses were as follows: 
Figure 1. Perception of China's media coverage of Africa

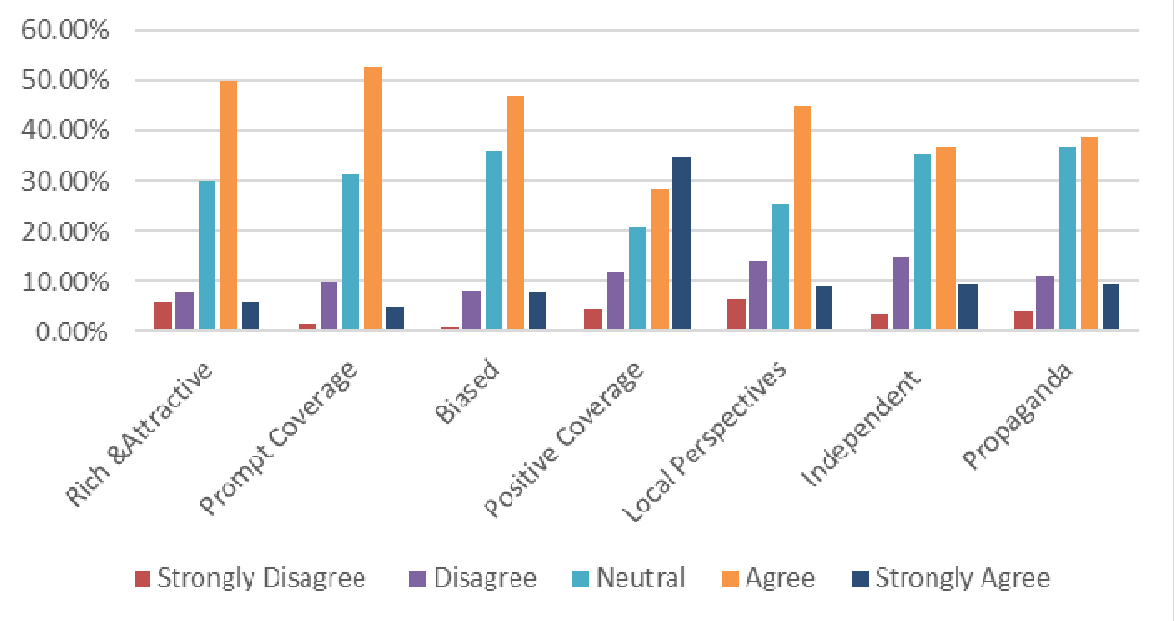

With regard to as whether or not the content of Chinese media is rich and attractive, $49.8 \%$ of the respondents agreed, while another $30 \%$ were neutral. A further $7.8 \%$ disagreed while the remaining $12.4 \%$ of the respondents were evenly split between the two extreme ends of the scale opting for strongly disagree and strongly agree respectively.

When a statement as to whether the Chinese media were prompt in their coverage was paused to them, $52.3 \%$ of the respondents were in agreement, $31.3 \%$ were neutral, $9.9 \%$ disagreed, $4.9 \%$ strongly agreed while $1.6 \%$ strongly disagreed. As to whether these media were biased in terms of their coverage's, $46.9 \%$ of the respondents agreed, while $35.8 \%$ opted to be neutral, $8.2 \%$ disagreed, $7.8 \%$ strongly agreed and $1.2 \%$ strongly disagreed.

One of the goals of Chinese media was to portray Africa positively. On this test, $34.6 \%$ of the respondents strongly agreed and another $28.4 \%$ agreed. However, $20.6 \%$ of the respondents were neutral, with $11.9 \%$ disagreeing and another $4.5 \%$ strongly disagreeing.

As to whether the coverage of Chinese media was based on the local perspectives, $44.9 \%$ of those polled agreed and $9.1 \%$ strongly agreed, while $25.5 \%$ of the respondents were neutral, $14 \%$ disagreed and $6.6 \%$ strongly disagreed. When the independence of these media was put to test, $36.6 \%$ of the respondents agreed and $9.5 \%$ strongly agreed. However, $35.4 \%$ of those polled were neutral, while $14.8 \%$ disagreed and $3.7 \%$ strongly disagreed.

With reference to whether the contents of these media were propaganda or not, $38.7 \%$ of the respondents agreed and $9.5 \%$ strongly agreed. Another $36.6 \%$ of the respondents were neutral, $11.1 \%$ disagreed and $4.1 \%$ strongly disagreed. 


\section{Discussion and Conclusion}

This study sought to investigate the Kenyan audience exposure to Chinese media in Africa, their motivations for the use of these media and their perceptions of the coverage of African issues. The final results generally indicated that $68.5 \%(n=355)$ of the respondents were exposed to Chinese news media. Although this result suggested that the Chinese news media were gaining grounds among the audience, this did not translate to their actual consumption in any significant way. These findings conformed to the previous studies that the consumption of Chinese media among the Kenyan audience was limited (Gorfinkel et al., 2014; Wasserman, 2018; Wasserman \& Morlaes, 2018; Zhang \& Mwangi, 2016).

With reference to the most accessible Chinese media outlet, this study revealed the existence of varied levels of audience accessibility to different media outlets. With the exception of the CCTV/CGTN which was perceived to have recorded a significant growth over the years, the accessibility to the rest of the media was unsatisfactory. Close to six years since CCTV and China daily have joined the already existing media, Xinhua and CRI in Kenya, the visibility of these media were rarely being felt in the country. The desire to boost the penetration of these media appeared to have dampened, with no significant effort put in place to aggressively attract for more audience. Be that as it may, while the audience limited knowledge of Xinhua was arguably understandable due to the nature of its services, equally unsatisfactory performance by CRI and China daily among the audience is hard to comprehend. It can be recalled that CRI initially teamed up with the national broadcaster, $\mathrm{KBC}$, to air its contents while China daily was available as a free circulation copy in the country. This collaboration between $\mathrm{KBC}$ and CRI was meant to boost joint audience base for these media outlets. However, since the availability of commercial (private) media in the country has significantly eroded KBC's audience share, this strategy has not translated to any substantial growth for the Chinese outlet either. Furthermore, KBC is also viewed as government propaganda and has many a times been accused of biased news as well, with scholars arguing that the government impedes its independence and capability to provide Kenyans with objective and reliable content (Nyabuga \& Booker, 2013).Thus, CRI's teaming up with the national broadcaster was not sufficient to enhance its penetration and popularity in the country..

In nutshell, it could be argued that the Chinese media is slowly gaining grounds into the Kenyan media scene as the audience not only identified these media accurately, but also indicated accessibility of the leading Chinese national media in Kenya as pointed out elsewhere in this study. However, this finding contradicted a recent assertion that the university students in Kenya and South Africa hardly ever choose Chinese media to be informed and also have limited knowledge of China's most international news organizations present in Africa (Wasserman \& Madrid-Morales 2018; Wasserman, 2018).

Nevertheless, this study suggested that audiences wanted more non-western news to consume alongside local and Western news in order to broaden their horizons or to compare and contrast different media outlets. This study indicated that although their level of consumption among the audience was limited, the Chinese media have the potential to attract more audience in future. It is noteworthy that, though small, a section of the audience gave their motivations for engaging Chinese media in order to be more knowledgeable about China while others simply wanted to entertain themselves. In light of these observations, it follows that, then China's news media 
were perceived to be providing somewhat an alternative media products from what the national and western media were offering.

\subsection{Perceptions about the Chinese media coverage of Africa}

With reference to audience perceptions of the Chinese media coverage of Africa, this study has demonstrated that the respondents were too cautious in their responses. By and large, the majority of the respondent's responses revealed patterns of adopting the middle grounds, thus avoiding the two extreme ends of the measurement scale. The position taken by the respondents over this subject is a reflection of the commonly held notion that China's media generally appeared to adopt neutral position on controversial issues while emphasizing the government's official events and positions in their daily occurrences. Nonetheless, this study generally suggested that the content of Chinese media is rich and attractive. This is in line with one of their fundamental goal of providing their audience with alternative source of information from the traditional western perspectives. In addition, this study showed that these media have demonstrated their commitments to execute their ambitious target of providing coverage based on the local perspectives as the majority of the respondents seemed to agree that this goal has fairly been attained. With huge resources, state of art equipment and facilities, coupled with technical expertise at its disposal, the Chinese media have the capacity to provide prompt coverage of events and happenings as they unfold in real time reporting. Though, as to whether this was a standard routine practice is contentious, the finding showed that the majority of the audience were affirmative that the coverage of Chinese media in Africa is prompt.

Despites increasing presence in the continent, Chinese media are yet to decisively convince their audiences in terms of their independence and their level of trustworthiness. This study suggested that the majority of the respondents perceived their contents as being biased, and government propaganda, thus have minimal trust in them. This can be attributed to fact that being state media, they may not completely enjoy editorial independence, which is a huge setback that is likely to influence the audience perception and approval ratings of their contents. This finding is also in stark contrast with widely held discernment about the impartiality of Chinese media on most of the controversial topics. This position resonated with the claims by Marsh (2016), that any efforts by the Chinese state media to influence their overseas audiences are habitually shackled by propaganda directives and self-censorship that they are being subjected to by their Beijing authorities. Further, Gagliardone et al. (2012) reasoned that despite the numerous initiatives pursued by the Chinese media to expand its presence in the continent, it is unlikely that these media will attract international audiences as long as their style of reporting continues to carry the burden of the party's strict guidelines.

Similarly, when Chinese media made inroads into the continent, they were received with some kind of ferment that finally the African voices can be heard from an African perspective in the international media arena. In a similar vein, China also aims to relay on its state media to redeem its image and reputation amongst the global community. As to whether the Chinese media have succeeded in providing positive coverage to Africa, this study suggested that the coverage of African issues is largely perceived as positive. 
By and large, this study indicated that while the audience exposure to the Chinese news media is fairly satisfactory, their perceived motivation for the use of these media is varied. Though there are still faced by some challenges, China's media coverage of African issues and events are generally perceived as adequate. Nevertheless, this study concluded that Chinese news media in Africa were perceived to be contributing to the creation of some knowledge and understanding of Sino-African narratives amongst their Africa audiences in general, Kenya in particular. It follows then that, the Afro-centric policy being pursued by these media were perceived to have yielded some desired outcomes. This argument partially resonated with Bailard's (2016) sentiment that, the sweeping efforts undertaken to expand the reach and relevance of Chinese media in Africa have moved African public opinion in the desired direction.

\subsection{Study Limitation}

Although this study has provided some insights into the perceived audience reception and motivation of the Chinese news media in Kenya, this study also has a limitation in that the sample size was small and limited to few universities in Nairobi, thus could not be sufficiently generalized to all the Kenyan university students, and the larger Kenyan audience. In future, similar such studies conducted in selected few African countries with heavy presence of Chinese media, and involving more heterogeneous audiences would likely to paint vividly a more accurate picture on the impact of these media at the continental level.

Notes

1. Although CCTV was rebranded to China Global Television Network (CGTN) in 2016, and subsequently CCTV Africa also changed to CGTN Africa, CCTV Africa was retained due to its familiarity with the audience, though the two names were used interchangeably in this study.

2. The public universities sampled for this study were University of Nairobi, Technical University of Kenya and Multimedia University of Kenya, and a national college, Kenya Institute of Mass Communication while private universities were Mount Kenya University, Pan-African Christian University and Riara University.

3. Based on Kothari's (2004) approach, the names of all the universities in Nairobi were written on a slip of paper, then the slips were put into a box and mixed thoroughly, and then drawn without replacement until the required number of slips for each category of the sample was reached.

4. This was a filter question in which those who were negative were requested to skip the subsequent questions in this section of the questionnaire.

\section{References}

Bailard, C. S.(2016), "China in Africa: An Analysis of the Effect of Chinese Media Expansion on African Public Opinion,” The International Journal of Press/Politics, 21(4),446-471.

Banda, F .(2009), "China in the African mediascape: A critical injection”, Journal of African Media Studies, 1(3),343-361.doi: 10.1386/jams.1.3.343/1.

BBC News .(2012), “China Daily newspaper launches African edition”,.BBC News. December, 14[Online] Available at: http://www.bbc.com/news/world-asia-china-20722952.(Accessed October 9, 2017).

Blumler, J. G. (1979), “The Role of Theory in Uses and Gratifications Studies', Communication Research, 6(1), 9-36. 
Cooper, A .(2008), "China Radio International: A New Presence in the African Media Market" In: Communication and Media Research Institute (CAMRI), Round-table Conference on China-Africa: What does it mean for the Media? London, United Kingdom, 17 September, University of Westminster: London.

Diakon, B., and Röschenthaler, U.(2017), “The Chinese presence in the Malian mediascape”, Journal of African Cultural Studies, 29(1),96-113.

Finlay, A.(2013), “Tracking the effects of a 'soft power' strategy on journalism in China", Ecquid Novi: African Journalism Studies, 34(3),155-160.

Gagliardone, I.(2013)," China as a persuader: CCTV Africa's first steps in the African mediasphere", Ecquid Novi: African Journalism Studies, 34(3),25-40.

Gagliardone, I., and Verhoeven, H.(2012), "New trends in African media: The growing role of China." OUCAN Conference report. Available at: https://oucan.politics.ox.ac.uk/index.php/past-conferences/new-trends-inafrican-media.(Accessed October 26, 2017).

Gagliardone, I., and Pál, N.(2017), "Freer but not free enough? Chinese journalists finding their feet in Africa." Journalism, 18(8), 1049-1063.

Gagliardone, I., Stremlau, N.,and Nkrumah, D.(2012), "Partner, prototype, or persuader? China's renewed media engagement with Ghana", Communication, Politics \& Culture, 45, 174-196.

Gagliardone I .(2014), “Media development with Chinese characteristics”, Global Media Journal, 4(2),1-16.

Gorfinkel, L., Joffe, S., Van Staden, C., and Wu, Y.(2014), “CCTV'S global outreach: examining the audiences of China's 'new voice' on Africa', Media International Australia, 151(1),81-88.

Grassi, S.(2014), “ Changing the Narrative: China’s Media Offensive in Africa”, International Policy Analysis, Friedrich-Ebert-Stiftung, Berlin: Germany. Retrieved from.http://library.fes.de/pdf-files/iez/10700.pdf.(Accessed October 25, 2017).

Gunter, B. (2000), "Media research methods: Measuring audiences, reactions and impact”, London: Sage.

Jiang, F., Li, S., Rønning, H.,and Tjønneland, E.(2016), “The voice of China in Africa: media, communication technologies and image-building', Chinese Journal of Communication ,9(1), 1-7.

Katz, E.,and Foulkes, D.(1962), "On the use of mass media for escape: Clarification of a concept" Public Opinion Quarterly, 26(3),377-388.

Katz E.,. Blumler, J. G.,and Gurevitch, M .(1973), “Uses and gratifications research”, Public Opinion Quarterly, 37(4),509- 523.

Leslie, M .(2016), "The Dragon Shapes Its Image: A Study of Chinese Media Influence Strategies in Africa”, African Studies Quarterly, 16(3-4),161-174.

Li, S., and Rønning, H.(2013), "Half-orchestrated, half freestyle: Soft power and reporting Africa in China", .Ecquid Novi: African Journalism Studies, 34(3),102-124.

Madrid-Morales, D., and Wasserman, H. (2017), "Chinese Media Engagement in South Africa what is its impact on local journalism?” Journalism Studies, DOI: 10.1080/1461670X.2016.1266280.

Marsh, V. (2016), “Mixed messages, partial pictures? Discourses under construction in CCTV's Africa Live compared with the BBC", Chinese Journal of Communication, 9 (1), 56-70.

McKenzie, D.(2012), "Chinese media make inroads into Africa”, CNN News, September 25. [Online] Available at: http://www.cnn.com/2012/09/05/business/china-africa-cctv-media/index.html.(Accessed September 20, 2017).

Nassanga, G. L., and Makara, S.(2016), "Perceptions of Chinese presence in Africa as reflected in the African media: case study of Uganda", Chinese Journal of Communication, 9(1), 21-37. 
Nyabuga, G., and Booker, Nancy. (2013), “Mapping Digital Media: Kenya country report”, Open Society Foundation, London, UK. Available at: http://www.opensocietyfoundations.org/sites/default/files/mapping-digital-media-kenya-20130321.pdf(Accessed September 17, 2017)

Nye, J. S., Jr. (2008), "Public diplomacy and soft power", ANNALS of the American Academy of Political and Social Science, 616, 94-109.

Shinn, D.(2012), “China's involvement in Mozambique”, International Policy Digest, August 2. [Online] Available at $:$ http://www.internationalpolicydigest.org/2012/08/02/chinas-involvement-inmozambique. (Accessed October 24, 2017).

Shinn, D. H., and Eisenman, J.(2012), “China and Africa: A Century of Engagement”, Philadelphia: University of Pennsylvania Press.

Vincent, R. C.,and Basil, M. D. (1997), “College students' news gratifications, media use, and current events knowledge", Journal of Broadcasting \& Electronic Media, 41(3),380-392.

Wasserman, H.(2013), “China in Africa: The implications for journalism”, Ecquid Novi: African Journalism Studies, 34(3), 1-5.

Wasserman, H.(2015), "South Africa and China as BRICS Partners: Media Perspectives on Geopolitical Shifts", Journal of Asian and African Studies, 50(1),109-123.

Wasserman, H.(2016), "China's "soft power" and its influence on editorial agendas in South Africa", Chinese Journal of Communication, 9(1), 8-20.

Wasserman, H.(2018), "China-Africa media relations: What we know so far", Global Media and China ,3(2), 108-112.

Wasserman, H., and Madrid-Morales, D. (2018) "How Influential Are Chinese Media in Africa? An Audience Analysis in Kenya and South Africa." International Journal of Communication, (12),2212 -2231. Available at http://ijoc.org/index.php/ijoc/article/view/7809/2355.(Accessed June 22,2018).

Wekesa, B.(2013), "Emerging trends and patterns in China-Africa media dynamics: A discussion from an East African perspective", Ecquid Novi: African Journalism Studies, 34(3), 62-78.

Wu, Y. (2016), "China's media and public diplomacy approach in Africa: illustrations from South Africa", Chinese Journal of Communication, 9(1), 81-97.

Wu, Y.(2012), "The rise of China's state-led media dynasty in Africa".South African Institute of International Affairs Occasional Paper 117, June. Available at https://www.africaportal.org/documents/7538/saia_sop 117 wu 20120618.pdf.(Accessed October 17, 2017).

Xiang, Y .(2018), “African Students Watching CCTV-Africa: A Structural Reception Analysis of Oppositional Decoding”, Westminster Papers in Communication and Culture, 13(1),123-142.

Xin, X. (2009), “Xinhua News Agency in Africa”, Journal of African Media Studies, 1(3), 363-377.

Zhang, X.(2013), “ How ready is China for a China-style world order? China's state media discourse under construction", Ecquid Novi: African Journalism Studies, 34(3), 79-101.

Zhang, X., Wasserman,H.,and Mano, W.(2016), “China's expanding influence in Africa: projection, perception and prospects in Southern African countries", Communicatio, 42(1), 1-22.

Zhang, Y., and Matingwina, S.(2016), "A new representation of Africa? The use of constructive journalism in the narration of Ebola by China Daily and the BBC", African Journalism Studies, 37(3), 19-40.

Zhang, Y., and Mwangi,. J. M.(2016), “A perception study on China's media engagement in Kenya: from media presence to power influence?”, Chinese Journal of Communication, 9(1),71-80. 